RASĀYAN J. Chem.

Vol. 13 | No. 3 |1363-1371| July - September | 2020 ISSN: 0974-1496 | e-ISSN: 0976-0083 | CODEN: RJCABP

RJC http://www.rasayanjournal.com http://www.rasayanjournal.co.in

\title{
POTENTIAL BENEFITS OF RESVERATROL DERIVATIVES FOR TREATMENT AND PREVENTION OF METABOLIC SYNDROMES
}

\author{
V. Saraswaty ${ }^{1,2}$, IK. Adnyana ${ }^{1, *}$, S. Pudjiraharti ${ }^{2}$ and H. Rachmawati ${ }^{1, *}$ \\ ${ }^{1}$ School of Pharmacy, Bandung Institute of Technology, Jl. Ganesha 10 Bandung 40132, \\ West Java Indonesia \\ ${ }^{2}$ Research Unit for Clean Technology, Indonesian Institute of Sciences, Jl. Cisitu Sangkuriang \\ Bandung 40135, West Java Indonesia \\ *E-mail : ketut@fa.itb.ac.id, h_rachmawati@fa.itb.ac.id
}

\begin{abstract}
Metabolic syndrome refers to risk factors that enhanced the development of cardiovascular disease and diabetes. Resveratrol is a stilbene compound. Various resveratrol derivatives have been isolated and identified from natural product extracts. Those compounds may present in the form of a monomer, dimers, trimers, or even more complex derivatives as the impact of structure modification during biosynthesis. Over the years, resveratrol and its derivatives have been explored on its pharmacological effects. In this paper, we reviewed the potency of several wellcharacterized resveratrol derivatives isolated from natural product extract for the treatment and prevention of metabolic syndromes. We reveal that resveratrol derivatives can be used for prevention and treatment metabolic syndromes such as obesity, diabetes, hyperuricemia, as well as an inflammatory condition by interfering multiple targets, for example inhibiting several enzymes including xanthine oxidase, lipase, $\alpha$-glucosidase, DPP-IV, and angiotensin-converting enzyme, activating PPAR- $\alpha$ and PPAR- $\beta / \delta$, reducing visceral adipose fat, as well as downregulating GLUT9 and URAT1 ion transporter. The potency of those resveratrol derivatives such as gnetin C (isolated from Gnetum gnemon seed) and mulberroside A (isolated from Morus alba) seem superior as compared with trans-resveratrol as its parental compound in vitro and exhibited positive effect in an animal model. Hence, we suggest natural product extract containing resveratrol derivatives may provide promising prospects as an alternative medicine for treatment and prevention of metabolic syndrome.
\end{abstract}

Keywords: Resveratrol Derivatives, Mulberroside A, Gnetin C, Metabolic Syndrome.

(c) RASĀYAN. All rights reserved

\section{INTRODUCTION}

According to the American Association of Clinical Endocrinologists (AACE) and World Health Organization (WHO), metabolic syndromes are generally signed by hypertension, high glucose level (type 2 diabetes mellitus), pro-inflammatory state (hyperuricemia), as well as dyslipidemia. ${ }^{1,2}$ Lots of epidemiological data demonstrate that daily food intake, physical activity, smoking, family history of diabetes as well as genetic background are remarkably associated with the prevalence of metabolic syndrome. Furthermore, the incidence of metabolic syndrome tends to increase year by year due to the changes in lifestyles. ${ }^{3-9}$ Against metabolic syndromes with natural product extract derived compounds appears to be a fascinating strategy because of its low toxicity and has a constructive effect as compared with the chemically synthesized drug.

Resveratrol (3,5,4'-trihydroxytrans-stilbene), is a stilbene compound present in several fruits and vegetables including grapes, peanut, itadori, and melinjo. ${ }^{10,11}$ During the last decade, numerous preclinical studies have shown that resveratrol and its derivatives attracted considerable attention because of its potency in the prevention of several ailments including cardiovascular disease, hyperuricemic, diabetes mellitus, as well as aging. Resveratrol and its derivatives are reported reducing blood serum uric acid, blood serum glucose, as well as blood serum cholesterol levels by inhibiting various enzyme activities Rasayan J. Chem., 13(3), 1363-1371(2020) http://dx.doi.org/10.31788/RJC.2020.1335815

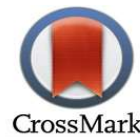


RASĀYAN J. Chem.

Vol. 13 | No. 3 |1363-1371| July - September | 2020

associated with those ailments that are xanthine oxidase, ${ }^{12}$ lipase, as well as amylase ${ }^{13}$ enzymes in vitro. However, those effects have not yet been confirmed in clinical trials using patients, due to the practical boundaries related to the investigation of metabolic syndromes.

In nature, resveratrol is biosynthesized in plants as a response to microbial infection, injury, as well as ultraviolet radiation..$^{10}$ The resveratrol derivatives can be found in the form of dimers, trimers, tetramers, and even more complex compounds as the impact of structure modification as well as complexation during biosynthesis. ${ }^{14-16}$ However, the biogenesis of these compounds has not been thoroughly understood. It seems that the coupling of regioisomeric modes generates broad resveratrol dimeric skeleton that can undergo various reaction then producing more complex structures. ${ }^{17}$

The investigations that some resveratrol and its derivatives possess pharmacological activities (Fig.-1), including antioxidant ${ }^{18-20}$, antimicrobial,${ }^{13}$ anticancer, ${ }^{21,22}$ antiobesity, ${ }^{23}$ antiaging, ${ }^{19,24,25}$ inhibitor of various enzyme, antihypertension, ${ }^{12,13}$ as well as anti-alzheimer disease, ${ }^{26}$ have carried out to generate the scientific interest in these resveratrol derivatives. It seems that most of resveratrol derivatives are obtained in small amounts from natural product extracts, and majorly previous investigations have focused on the evaluation of its monomer (trans-resveratrol). ${ }^{27-31}$ Hence the pharmacological activities of only several resveratrol derivatives have been well studied. Although several of these compounds are reported having pharmacological effects related to metabolic syndromes, most of them only have tested in vitro (Table 1). Hence, it is not surprising that safety assessment as well as pharmacokinetic data of these resveratrol derivatives are lack and scarce.

A lot of investigations have shown the various potential of resveratrol derivatives as an alternative drug to prevent and treat metabolic syndrome, so far there is no systematic review about the potency of those compounds. In this paper, we resume the pharmacological activities of several resveratrol derivatives whose structure can be seen in Fig.-2, for the prevention and treatment of metabolic syndromes associated with obesity, type 2 diabetes mellitus, hyperuricemic, as well as inflammation and propose the action mechanism.

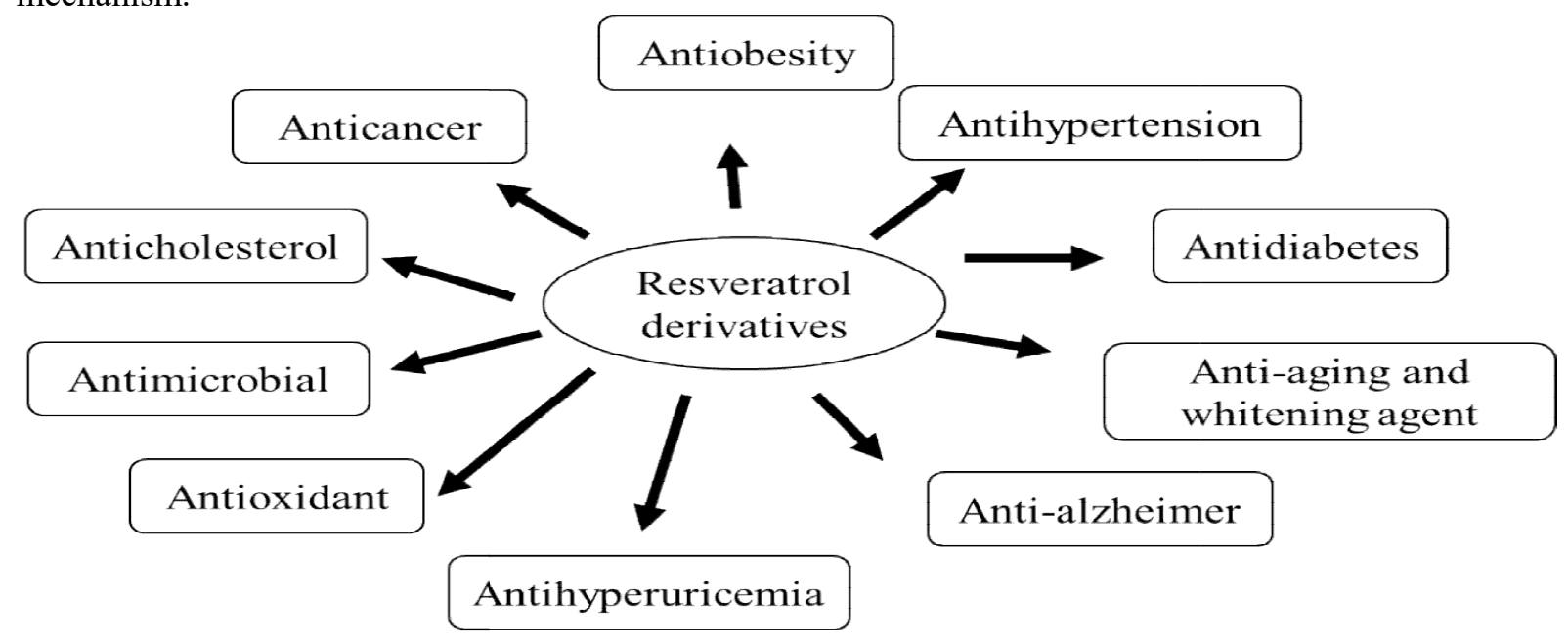

Fig.-1: Pharmacological Activities of Resveratrol Derivatives

Table-1: Naturally Resveratrol Derivatives with Anti-metabolic Syndromes Potentia

\begin{tabular}{|c|c|c|c|c|}
\hline $\begin{array}{l}\text { Resveratrol } \\
\text { Derivatives }\end{array}$ & Source & Mechanism of Action & $\begin{array}{c}\text { In vitro/in } \\
\text { vivo/Clinical } \\
\text { Trial }\end{array}$ & Reference \\
\hline Mulberroside A & Morus alba & $\begin{array}{l}\text { Downregulating GLUT9 and } \\
\text { URAT1; upregulating OAT1, } \\
\text { OCT1, OCT2, OCTN1, and } \\
\text { OCTN2; suppressing NO and } \\
\text { iNOS expression }\end{array}$ & In vitro, in vivo & $32-34$ \\
\hline Gnetin C & $\begin{array}{l}\text { Gnetum } \\
\text { gnemon seed }\end{array}$ & $\begin{array}{l}\text { Inhibiting xanthine oxidase, } \\
\text { Lipase and } \alpha \text {-amylase enzymes }\end{array}$ & $\begin{array}{l}\text { In vitro, in vivo, } \\
\text { clinical trial }\end{array}$ & $12,13,35-38$ \\
\hline
\end{tabular}


RASĀYAN J. Chem.

Vol. 13 | No. 3 |1363-1371| July - September | 2020

\begin{tabular}{|c|c|c|c|c|}
\hline Gnemonoside D & $\begin{array}{l}\text { Gnetum } \\
\text { gnemon seed }\end{array}$ & Inhibiting lipase enzyme & In vitro & 13 \\
\hline Gnetin L & $\begin{array}{l}\text { Gnetum } \\
\text { gnemon seed }\end{array}$ & Inhibiting lipase enzyme & In vitro & 13 \\
\hline Gnetin $\mathrm{H}$ & $\begin{array}{l}\text { Paeonia } \\
\text { lactiflora }\end{array}$ & $\begin{array}{l}\text { Inhibiting } \alpha \text {-glucosidase, DPP- } \\
\text { IV, and PTP1B enzyme; } \\
\text { Suppressing cytokine response } \\
\text { involved in the NF- } \kappa \text { B pathway. }\end{array}$ & In vitro & $39-41$ \\
\hline$\alpha$-Viniferin & $\begin{array}{l}\text { Caragana } \\
\text { chamlagu root }\end{array}$ & $\begin{array}{l}\text { Inhibiting LPO activity, COX-2 } \\
\text { and iNOS }\end{array}$ & In vitro & 42 \\
\hline Hopeaphenol & $\begin{array}{l}\text { Vateria indica } \\
\text { Linn stem bark } \\
\text { and } \\
\text { Ampelocissus } \\
\text { indica } \\
\text { rhizome }\end{array}$ & $\begin{array}{l}\text { Inhibiting } \alpha \text {-glucosidase } \\
\text { enzyme; lowering plasma lipase } \\
\text { activity }\end{array}$ & In vitro, in vivo & $43-46,47$ \\
\hline Vitisin A & $\begin{array}{l}\text { ethanol extracts } \\
\text { of } \quad \text { Vitis } \\
\text { thunbergii var. } \\
\text { taiwaniana } \\
\text { stem. }\end{array}$ & $\begin{array}{l}\text { Inhibiting } \quad \alpha \text {-glucosidase and } \\
\text { DPP-IV, ACE enzyme; } \\
\text { lowering plasma lipase } \\
\text { activities, reducing weight; }\end{array}$ & In vivo, in vitro & $47-49$ \\
\hline Vaticanol B & $\begin{array}{l}\text { Shorea gibbosa } \\
\text { bark. }\end{array}$ & $\begin{array}{l}\text { Reducing visceral adipose fat; } \\
\text { Reducing the protein load and } \\
\text { maintaining the membrane } \\
\text { integrity of the ER. }\end{array}$ & In vivo, in vitro & $50-52$ \\
\hline Vaticanol C & $\begin{array}{l}\text { Vatica rassak, } \\
\text { Shorea } \\
\text { roxburghii and } \\
\text { Vatica } \\
\text { pauciflra. }\end{array}$ & $\begin{array}{l}\text { Activating PPAR- } \alpha \text { and PPAR- } \\
\beta / \delta\end{array}$ & In vitro, in vivo & $53-55,59,56$ \\
\hline
\end{tabular}

\section{Mulberroside A}

Mulberroside A (1), is a glycosylated resveratrol monomer that has been isolated from several species of the Moraceae family including Morus alba and Ramulus mori. Mulberroside A isolated from Morus alba root has been evaluated for its anti-hyperlipidemic effects in an animal model. ${ }^{32,33}$ Oral administration Mulberroside $\mathrm{A}$ at 1 to $5 \mathrm{mg} / \mathrm{kg}$ bw significantly reduced blood serum lipids level in induced hyperlipidemic rats. ${ }^{33}$ Mulberroside A was reported downregulating mRNA and protein levels of renal glucose transporter 9 (mGLUT9) and urate transporter 1 (mURAT1) in induced hyperuricemic mice. Also, this compound was reported upregulating mRNA and protein levels of renal organic anion transporter 1 (mOAT1) and carnitine transporters (mOCT1, mOCT2, mOCTN1, and mOCTN2), ${ }^{34}$ indicating its potential as antihyperuricemic and nephroprotective agent.

There is growing evidence that silent chronic inflammation is one of the key factors in metabolic syndrome and cardiovascular disease.$^{57}$ cis-Mulberroside A was reported exhibiting suppressive effect on the NO production and inducible nitric oxide synthase (iNOS) expression in lipopolysaccharide (LPS)stimulated macrophage, suggesting a strong potency as an anti-inflammatory as well as analgesic agent. ${ }^{32}$ Following the results of antihyperuricemic, antihyperlipidemic as well as antiinflammation effect in an animal model, Mulberroside A has considerable therapeutic potential in the prevention of metabolic syndrome and merits for being considered to be tested in clinical trials for cardiovascular therapeutic.

\section{Gnetin C}

Gnetin C (2) is a resveratrol dimer that has been isolated from several species of Gnetaceae including melinjo or Gnetum gnemon. ${ }^{13}$ This compound also can be found in $G$. africanum and $G$. schwackeanum. ${ }^{35-36}$ The ethanol extract of melinjo seeds is rich in resveratrol and its derivatives including gnetin C, gnemonoside A (3), gnetin L (4) as well as other stilbene derivatives. Consumption of melinjo seed extract at $750 \mathrm{mg} /$ day for 8 weeks was well tolerated and decreased blood serum uric acid level in 
RASĀYAN J. Chem.

Vol. 13 | No. 3 |1363-1371| July - September | 2020

non-obese males (Japanese) healthy volunteers. As a single compound, gnetin $\mathrm{C}$ inhibited $50 \%\left(\mathrm{IC}_{50}\right)$ xanthine oxidase (XO) enzyme activity at $133 \mu \mathrm{g} / \mathrm{mL} .^{12}$ The potency of gnetin $\mathrm{C}$ as XO inhibitor looks superior as suggested by its lower $\mathrm{IC}_{50}$ value compared with its parental compound (trans-resveratrol). Based on the chemical structure, we suggest that in the form of dimer, resveratrol derivative is more active as $\mathrm{XO}$ inhibitor.

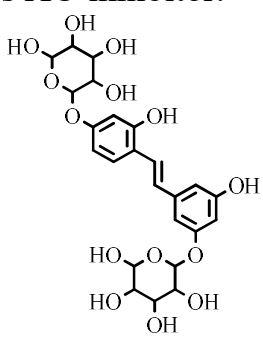

(1)

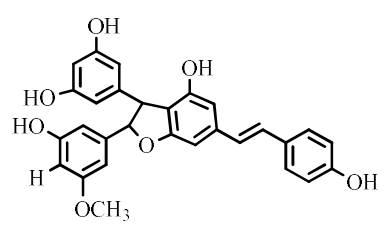

(4)

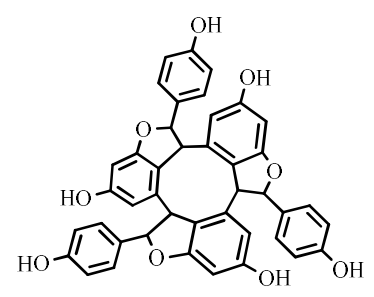

(7)

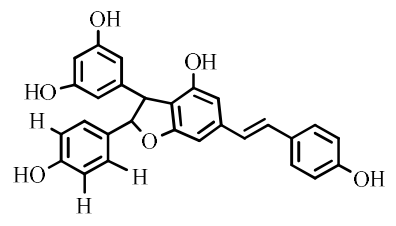

(2)

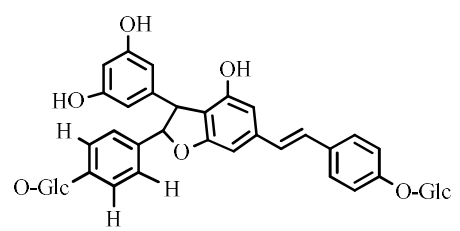

(3)

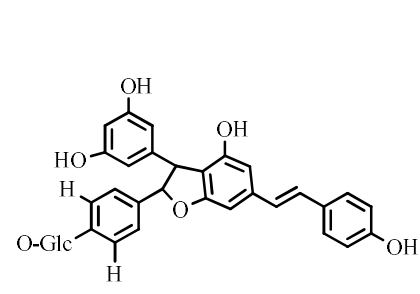

(5)

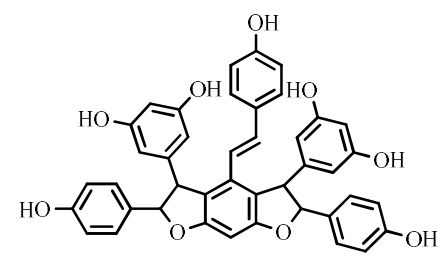

(6)

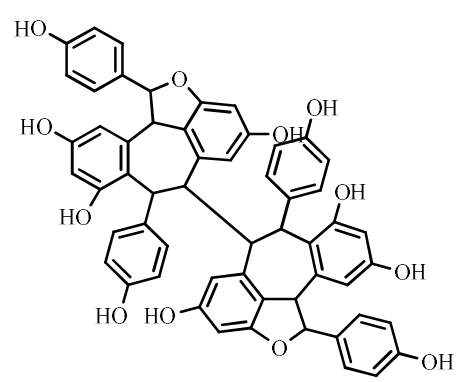

(8)

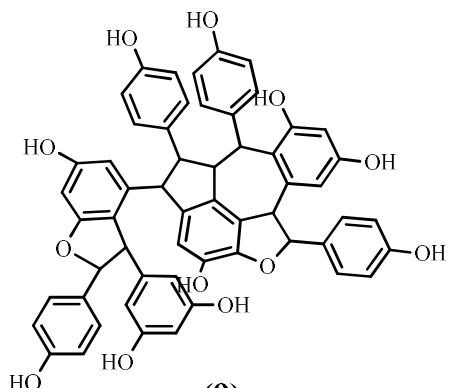

(9)

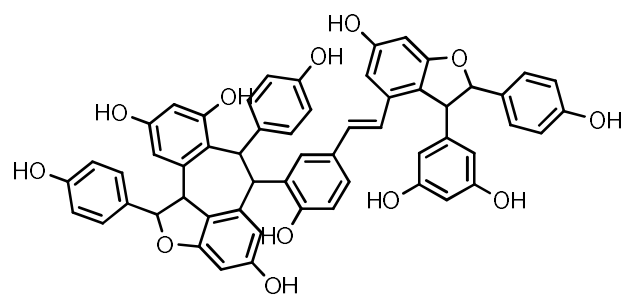

(10)

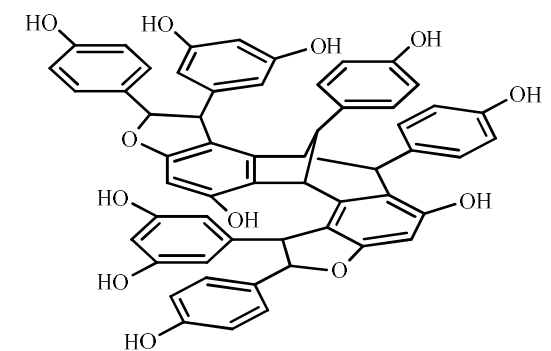

(11)

Fig.-2: Chemical Structure of Naturally Resveratrol Derivatives

It seems, that melinjo seed extract is also a potential source of antiobesity and anti-diabetes agents as suggested by the potency of gnetin $\mathrm{C}$, gnetin $\mathrm{L}$ and gnemonoside $\mathrm{C}$ (5) inhibiting the lipase and $\alpha$ amylase enzyme. ${ }^{13}$ The potency of gnetin $\mathrm{C}$ to prevent metabolic syndrome including obesity, hyperuricemic, and cardiovascular disease was emphasized in the clinical trial whose results show that consumption of pure gnetin $\mathrm{C}$ at $150 \mathrm{mg} /$ day remarkably decreased the blood serum uric acid, low-density lipoprotein cholesterol, high-density lipoprotein cholesterol, total adiponectin, and high-molecular-weight adiponectin level. ${ }^{37}$ 
RASĀYAN J. Chem.

Vol. 13 | No. 3 |1363-1371| July - September | 2020

The pharmacokinetic profile of gnetin $\mathrm{C}$ has been studied. A study reported that the mean residence time (MRT) of gnetin $\mathrm{C}$ was $36 \mathrm{~h}$ and less for trans-resveratrol (MRT of $24 \mathrm{~h}$ ), and gnetin $\mathrm{C}$ was still present in the blood plasma for up to $96 \mathrm{~h}^{38}$ Those results were also supported by an investigation reporting higher concentration of gnetin $\mathrm{C}$ than trans-resveratrol in blood serum of streptozotocin-induced diabetic mice after oral administration of melinjo seed extract, showing the longer bioavailability of gnetin $\mathrm{C}$ than trans-resveratrol. ${ }^{58}$ A study also reported that melinjo seed extract was well tolerated up to $1000 \mathrm{mg} / \mathrm{kg}$ bw in mice without any sign of adverse effect or toxicity. ${ }^{59}$ Hence, we suggest that either gnetin $\mathrm{C}$ or melinjo seed extract is safe for being consumed.

In summary, those above data evidence the potential benefits and safety of gnetin $\mathrm{C}$. Thus, natural product extract containing a large amount of gnetin $\mathrm{C}$ including melinjo (Gnetum gnemon) should be considered for being developed as an alternative medicine for prevention and treatment of metabolic syndrome. ${ }^{22}$ However due to the clinical trials only provided data from healthy volunteers, therefore further works are needed to confirm the biological effect in patients with metabolic disorder condition.

\section{Gnetin H}

Gnetin H (6) is a resveratrol trimer isolated from Paeonia lactiflora. This compound has been reported possessing anti-diabetes (type 2 diabetes mellitus) properties, as suggested by inhibition of $\alpha$-glucosidase, dipeptidyl peptidase-4 (DPP-IV) and protein tyrosine phosphatase 1B (PTP1B) enzyme activity. Trans gnetin $\mathrm{H}$ inhibited those enzyme activities greater than that of cis form. ${ }^{39}$ Also, experiments evidence showed that cis- and trans-gnetin H suppressed cytokine response in LPS-stimulated THP-1 cells by preventing activation of key signaling molecules, IKK- $\beta$, I $\mathrm{KB} \alpha$, and $\mathrm{p} 65$, involved in the nuclear factor kappa B (NF-kB) pathway. ${ }^{40}$ Thus, despite the potency of gnetin $\mathrm{H}$ as an anti-diabetes agent, this compound also exhibits an anti-inflammatory effect. ${ }^{41}$ Hence, gnetin $\mathrm{H}$ has the potential to prevent and treat metabolic syndrome. However, further studies either in an animal model and clinical trial in healthy individuals or patients should be carried out to warrant this biological activity.

\section{$\alpha-V i n i f e r i n$}

$\alpha$-Viniferin (7) is trimeric resveratrol isolated from an n-hexane extract of Caragana chamlagu root. ${ }^{60}$ Pharmacological studies have shown that $\alpha$-viniferin inhibited lipid peroxidation (LPO) and inflammatory activity. ${ }^{42,61}$ The inflammatory activity of $\alpha$-viniferin was suggested by inhibition of cyclooxygenase-2 (COX-2) as well as iNOS activity. ${ }^{61}$ Additionally, $\alpha$-viniferin also exhibited a powerful anti-inflammatory activity by suppressing ERK-mediated STAT1 activation in interferon- $\gamma$-stimulated macrophages. ${ }^{62}$ Together, those studies reveal that $\alpha$-viniferin interacts with several targets associated with inflammatory as well as obesity condition. Suggesting natural product containing large amount of $\alpha$-viniferin merits for being considered as alternative medicine for treatment of obesity as well as inflammation. However, due to the lack of in vivo investigations as well as the safety assessment of this compound, we suggest performing more in vivo experiments to ensure the biological activities.

\section{Hopeaphenol}

Hopeaphenol (8) is a resveratrol tetramer that has been isolated from several species of the Vitaceae, Dipterocarpaceae, Cyperaceae and Fabaceae family. ${ }^{43-46}$ Purified Hopeaphenol from acetone extract of Vateria indica Linn stem bark and Ampelocissus indica (L.) rhizome was reported significantly inhibiting $\alpha$-glucosidase enzyme, showing its potential to treat type 2 diabetes mellitus. ${ }^{46}$ Surprisingly, in an experiment using animal model, oral administration of hopeaphenol at $25 \mathrm{mg} / \mathrm{kg}$ bw did not show a reduction of body weight. However, at the same dose this compound lowered plasma lipase activities. ${ }^{47}$ Thus, we expect that the potency of hopeaphenol at a dose of $25 \mathrm{mg} / \mathrm{kg}$ bw is less effective to ameliorate obesity and required higher dose. In addition, as suggested the efficacy of this compound tends to associate with enzymes. Likewise, despite the potency of hopeaphenol in prevention of metabolic syndrome, however, those pharmacological data are lack and scarce. We suggest to do further investigations in vivo to clarify this biological activity.

\section{Vaticanol B}

Vaticanol B (9) is a resveratrol tetramer that has been isolated from methanol extract of the tree bark of Shorea gibbosa. ${ }^{50}$ This compound largely found in Dipteroceae family. ${ }^{55} \mathrm{In}$ an experiment, treatment of 
RASĀYAN J. Chem.

Vol. 13 | No. 3 |1363-1371| July - September | 2020

zebrafish with Vaticanol B showed antiobesity activity that was almost similar in potency to that of resveratrol. ${ }^{51}$ Vaticanol B was reported reducing the protein load on the endoplasmic reticulum (ER) and maintaining the membrane integrity of the ER. ${ }^{52}$ It should be noted that type 2 diabetes mellitus induces oxidative stress as well as ER stress of the endothelium which play major roles in the initiation and progression of cardiovascular clinical manifestations. ${ }^{63}$ Hence, the potency of vaticanol $\mathrm{B}$ in the regulation of ER stress may reduce the risk of diabetes mellitus complication as well as metabolic syndromes. It seems that the scarce of pharmacokinetic study as well as safety assessment in vivo and humans are the main limitations of applying the therapeutic potential of this compound.

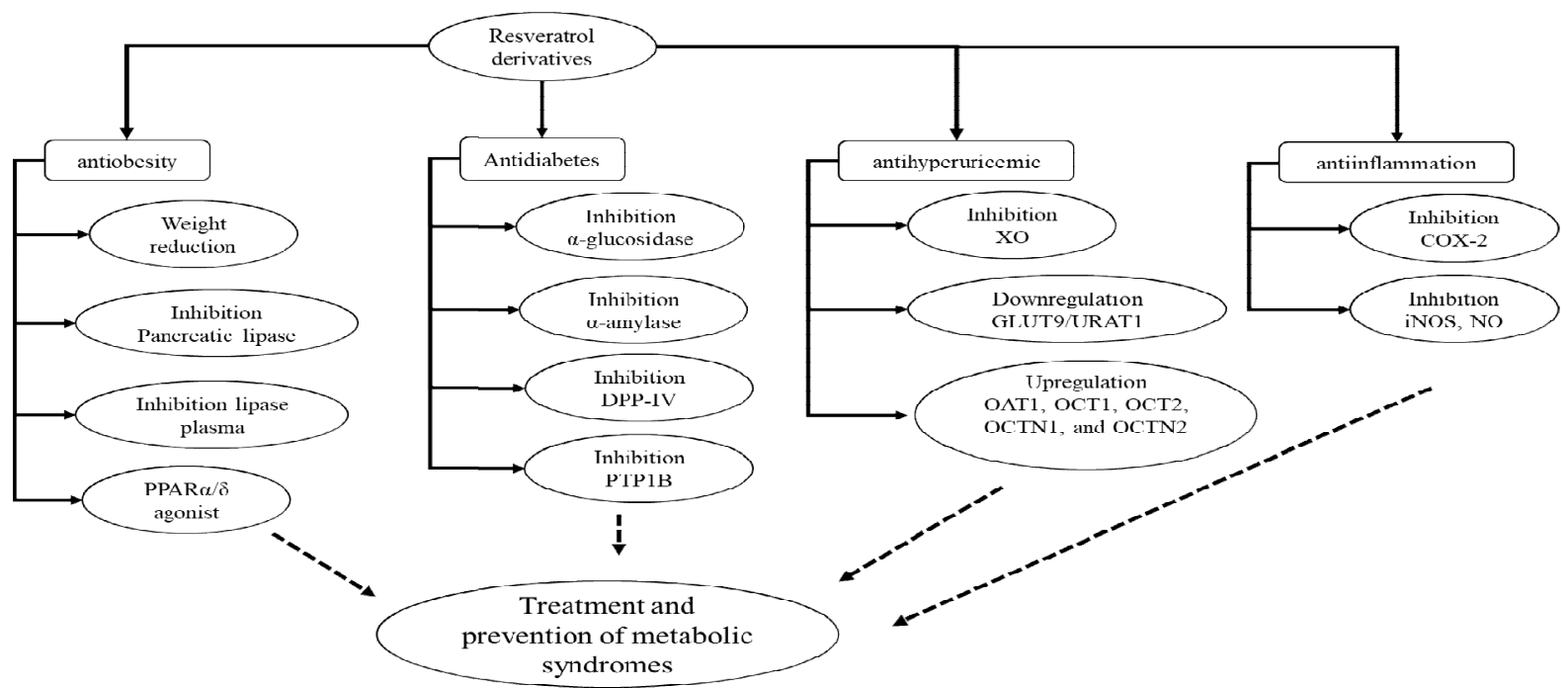

Fig.-3: Mechanism Action of Resveratrol Derivatives in the Prevention and Treatment of Metabolic Syndromes

\section{Vitisin A}

Vitisin A (10) is a resveratrol tetramer isolated from ethanol extracts of Vitis thunbergii var. taiwaniana and Ampelopsis brevipedunculata var. hancei (Planch.) Rehder. ${ }^{48-49}$ The pharmacological activities related with metabolic syndromes of vitisin A have been studied in animal model. Mice treated with vitisin A at $25 \mathrm{mg} / \mathrm{kg}$ bw showed a significant weight reduction as compared with obese mice. ${ }^{47}$ Also, vitisin A also showed antidiabetes activity as presented by inhibition of $\alpha$-glucosidase as well as DPP-IV enzyme. ${ }^{48}$ Interestingly, a study reported that vitisin A is a potent angiotensin converting enzyme inhibitor, showing its efficacy to reduce blood pressure. ${ }^{49}$ These data show that vitisin $\mathrm{A}$ is an excellent candidate for the treatment and prevention of obesity, type 2 diabetes mellitus as well as hypertension. Hence, the natural product extract containing vitisin A may be used for alternative treatment and prevention of metabolic syndrome. However, due to the lack of clinical trial as well as safety assessment data, the development of this compound is still limited.

\section{Vaticanol C}

Vaticanol C (11) is resveratrol tetramer that has been isolated from diverse Dipterocarpaceae species, including Vatica rassak, Shorea roxburghii and Vatica pauciflra. ${ }^{53-55}$ This compound has been reported exhibiting various biological activities such as antioxidant, anticancer, anti-inflammatory as well as antiobesity. ${ }^{53,64}$ In an experiment of antiobesity activity, vaticanol $\mathrm{C}$ was found activating PPAR- $\alpha$ and PPAR- $\beta / \delta$ both in vitro and in vivo. Therefore vaticanol $\mathrm{C}$ may efficiently reduce the body weight. ${ }^{56}$ Hence, we suggest that plant containing vaticanol $\mathrm{C}$ is a promising therapeutic agent for treating metabolic syndromes in particular for patients with obesity. Unfortunately, the safety assessment as well as pharmocokinetic profile of this compound has not been evaluated.

Finally, we propose the mechanism of action of resveratrol derivatives in the prevention and treatment of metabolic syndrome (Fig.-3). It is presented that resveratrol derivatives tend to interfere with various targets and inhibit several enzymes which are directly associated with obesity, hyperuricemia, type 2 diabetes mellitus as well as inflammation, hence, possible to treat and prevent metabolic syndromes. 
RASĀYAN J. Chem.

Vol. 13 | No. 3 |1363-1371| July - September | 2020

\section{CONCLUSION}

Resveratrol derivatives present in nature have been investigated in pre and clinical trials. However, resveratrol derivatives are rarely studied due to their small amount quantity except mulberroside A and gnetin C. Some purified resveratrol derivatives from different kinds of plants exhibit greater pharmacological activity than that of its parental compound (trans-resveratrol). The relevant investigations have shown that resveratrol derivatives are a promising anti-diabetes, anti-cholesterol, antiinflammatory, antihyperuricemic, as well as anti-obesity agent, thus possible to be applied in the prevention and treatment of metabolic syndromes. It should be noted that results from in vitro and in vivo studies are not always similar to those obtained from clinical studies due to the complex biological system. Accordingly, we suggest performing a large number of well-controlled and long-term clinical studies of resveratrol derivatives to warrant the pharmacological efficacy. There is also a need to observe whether the various pharmacological effect of resveratrol derivatives could give antagonist or synergistic effects. Although most of the scientific investigations on the pharmacological activities of resveratrol derivatives have shown its efficacy, however its exact mechanism of those compounds in the prevention and treatment of metabolic syndromes has not yet been fully studied and understood, hence further investigations are urgently needed. Finally, we also suggest that natural product extract contains high levels of resveratrol derivatives merit for being developed as an alternative medicine for the treatment and prevention of metabolic syndromes.

\section{ACKNOWLEDGMENT}

This work was supported by Research KK-A ITB under IKA in the funding year of 2018. Authors also thank Ministry of Research Technology for Doctoral scholarship (SAINTEK) under Vienna Saraswaty.

\section{REFERENCES}

1. K.G.M.M. Alberti, P.Z. Zimmet, Diabetic Medicine, 15(7), 593(1998), DOI:10.1002/(SICI)10969136(199807)15:7<539::AID-DIA668>3.0.CO;2-S

2. D. Einhorn, Endocrine Practice, 9, 23(2003), DOI:10.4158/ep.9.s2.5

3. S. Desroches, B. Lamarche, Applied Physiology, Nutrition Metabolism, 32(1), 23(2007), DOI: 10.1139/H06-095.

4. P. Kempegowda, S.R. Marcus, P. Solanki, R.S. Reddy, D.R. Nandini, M. Dharmalingam, International Journal of Diabetes in Developing Countries, 31(4), 188(2011), DOI:10.1007/s13410011-0046-y

5. G. Hu, J. Lindström, P. Jousilahti, M. Peltonen, L. Sjöberg, R. Kaaja, J. Sundvall, J. Tuomilehto, Journal of Clinical Endocrinology Metabolisme, 93(3), 832(2008), DOI:10.1210/jc.2007-1883

6. P.J. Nestel, R. Lyu, L.P. Low, W.H.H. Sheu, W. Nitiyanant, I. Saito, C.E. Tan, Asia Pacific Journal of Clinical Nutrition, 16(2), 362(2007), DOI:10.6133/apjen.2007.16.2.23.

7. H.K. Choi, E.S. Ford, C. Li, G. Curhan, Arthritis \& Rheumatism (Arthritis Care \& Research). 57(1). 109(2007), DOI:10.1016/j.amjmed.2006.06.040

8. Y. Zheng, R. Stein, T. Kwan, C. Yu, J. Kwan, S.L. Chen, Clinical Cardiology, 32(9), 491(2009), DOI: $10.1002 /$ clc. 20605

9. S. Bilici, G. Akbulut, N. Acar Tek, H. Yildiran, E. Koksal, M.G. Karadag, N. Sanlier, African Journal Biotechnology, 10(66), 14977(2011), DOI:10.5897/AJB11.3291

10. J. Burns, T. Yokota, H. Ashihara, M.E.J. Lean, A. Crozier, Journal of Agricultural, Food and Chemistry, 50(11), 3337(2002), DOI:10.1021/jf0112973.

11. T. Ikuta, S. Saito, H. Tani, T. Tatefuji, K. Hashimoto, Bioscience Biotechnology and Biochemistry. 23, 1(2015), DOI: 10.1080/09168451.2015.1056510.

12. H. Konno, Y. Kanai, M. Katagiri, T. Watanabe, A. Mori, T. Ikuta, H. Tani, S. Fukushima, T. Tatefuji, T. Shirasawa, Evidence-based Complement Alternative Medicine, 2013, (2013), DOI: $10.1155 / 2013 / 589169$.

13. E. Kato, Y. Tokunaga, and F. Sakan, Journal of Agricultural and Food Chemistry, 57(6), 2544(2009), DOI: $10.1021 / \mathrm{jf} 803077 \mathrm{p}$

14. M.H. Keylor, B.S. Matsuura, C.R.J. Stephenson, Chemical Reviews, 115(17), 8976(2015), DOI: $10.1021 / \mathrm{cr} 500689 \mathrm{~b}$ 
RASĀYAN J. Chem.

Vol. 13 | No. 3 |1363-1371| July - September | 2020

15. S. He, X. Yan, Current Medicinal Chemistry, 20(8), 1005(2013), DOI: $10.2174 / 0929867311320080004$

16. D. Delmas, Resveratrol: Sources, Production and Health Benefits, Nova Biomedical, (2013).

17. S.A. Snyder, A. Gollner, M.I. Chiriac, Nature, 474(7352), 461(2011), DOI:10.1038/nature10197

18. T.M. Siregar, E. Budianto, H. Cahyana, W. Wibowo, Rasayan Journal of Chemistry, 11(4), 1765(2018), DOI: 10.31788/RJC.2018.1143051

19. Sumaiyah, B.M Leisyah, Rasayan Journal of Chemistry, 12(3), 1185(2019), DOI: 10.31788/RJC.2019.1235337

20. Y. Taufik, T. Widiantara, Y. Garnida, Rasayan Journal of Chemistry, 9(4), 889(2016).

21. J.L. Espinoza, P.T. Inaoka, Annals New York Academy Science, 1403(1), 5(2017), DOI: 10.1111 /nyas.13450.

22. N.K. Narayanan, K. Kunimasa, Y. Yamori, M. Mori, H. Mori, K. Nakamura, G. Miller, U. Manne, A.K. Tiwari, B. Narayanan, Cancer Medicine, 2015, 1767(2015), DOI:10.1002/cam4.520.

23. T. Ikuta, S. Saito, H. Tani, T. Tatefuji, K. Hashimoto, Bioscience Biotechnology Biochemistry. 79(12), 2044(2015), DOI:10.1080/09168451.2015.1056510

24. M. Yanagihara, M. Yoshimatsu, A. Inoue, T. Kanno, T. Tatefuji, K. Hashimoto, Biological and Pharmaceutical Bulletin, 35(6), 993(2012), DOI:10.1248/bpb.35.993.

25. K. Ohguchi, T. Tanaka, T. Ito, M. Inuma, K. Matsumoto, Y. Akao, Y. Nozawa, Bioscience, Biotechnology and Biochemistry. 67(3). 663 (2003), DOI:10.1271/bbb.67.663

26. S. Seino, T. Kimoto, H. Yoshida, K. Tanji, T. Matsumiya, R. Hayakari, K. Seya, S. Kawaguchi, K. Tsuruga, H. Tanaka, T. Imaizumi, Biomedical Research, 39(3), 105(2018), DOI: $10.2220 /$ biomedres.39.105

27. U. Etxeberria, R. Castilla-Madrigal, M.P. Lostao, J.A. Martinez, F.I. Milagro, Cellular and Molecular Biology, 61(8), 9(2015), DOI:10.14715/cmb/2015.61.8.2

28. X.H. Zhang, B. Huang, S.K. Choi, and J.S. Seo, Nutrition Research and Practice, 6(4), 286(2012), DOI:10.4162/nrp.2012.6.4.286

29. I. Milton-Laskibar, S. Gómez-Zorita, L. Aguirre, A. Fernández-Quintela, M. González, M.P. Portillo, Molecules, 22(12), (2017), DOI: 10.3390/molecules22122091

30. J. Vanamala, L. Reddivari, S. Radhakrishnan, C. Tarver, BMC Cancer, 10, (2010), DOI: $10.1186 / 1471-2407-10-238$.

31. E.W.C. Chan, C.W. Wong, Y.H. Tan, J.P.Y Foo, S.K. Wong, H.T. Chan, Journal of Applied Pharmaceutical Science, 9(7), 124(2019), DOI:10.7324/JAPS.2019.90717

32. Z. Zhang, L. Shi, Fitoterapia, 81(3), 214(2010), DOI:10.1016/j.fitote.2009.09.005

33. S.P. Jo, J.K. Kim, Y.H. Lim, Food and Chemical Toxicology, 65, 213(2014), DOI: 10.1016/j.fct.2013.12.040

34. C.P. Wang, Y. Wang, X. Wang, X. Zhang, J.F. Ye, L.S. Hu, L.D. Kong, Planta Medica, 77(8), 786(2011), DOI:10.1055/s-0030-1250599.

35. N. Esser, N. Paquot, A.J. Scheen, Expert Opinion in Investigation Drugs, 24(3), 283(2015), DOI: $10.1517 / 13543784.2015 .974804$.

36. I. Iliya, T. Tanaka, M. Iinuma, Z. Ali, M. Furasawa, K. Nakaya, Heterocycles, 57(6), 1057(2002), DOI: $10.3987 / \mathrm{com}-02-9471$

37. A.M. Giesbrecht, A. Purchio, K. Ujikama, M.N.S. Ribeiro, Acta Amazonica, 15(3-4), 321(1985), DOI: $10.1590 / 1809-43921985153325$

38. Y. Nakagami, S. Suzuki, J.L. Espinoza, L. Vu-Quang, M. Enomoto, S. Takasugi, A. Nakamura, T. Nakayama, H. Tani, I. Hanamura, A. Takami, Nutrients, 11(6), E1403(2019), DOI: $10.3390 /$ nu1 1061403

39. T. Tatefuji, M. Yanagihara, S. Fukushima, K. Hashimoto, Food Chemical Toxicology, 67. 230(2014), DOI: $10.1016 /$ j.fct.2014.02.030

40. H. Tani, S. Hikami, S. Iizuna, M. Yoshimatsu, T. Asama, H. Ota, Y. Kimura, T. Tatefuji, K. Hashimoto, K. Higaki, Journal of Agricultural and Food Chemistry, 62(8), 1999(2014), DOI: $10.1021 / j$ f4048435 
41. H. Ota, M. Akishita, H. Tani, T. Tatefuji, S. Ogawa, K. Iijima, M. Eto, T. Shirasawa, Y. Ouchi, Journal of Natural Products, 76(7), 1242(2013), DOI:10.1021/np300841v

42. C.C. Zhang, C.A. Geng, X.Y. Huang, X.M. Zhang, J.J. Chen, Journal of Agricultural and Food Chemistry, 67(24), 6765(2019), DOI:10.1021/acs.jafc.9b01193

43. H.S. Park, E.J. Vick, Y. Gao, C. He, N.M. Almosnid, M. Farone, A.L. Farone, Journal of Ethnopharmacology, 189, 202(2016), DOI:10.1016/j.jep.2016.05.042

44. R.G. Baker, M.S. Hayden, S. Ghosh, Cellular Metabolism, 13(1), 11(2011), DOI:10.1016/j.cmet.2010.12.008

45. S. Kitanaka, M. Takido, T. Ikezawa, K. Yasukawa, S. Yamanouchi, Chemical and Pharmaceutical Bulletin, 38(2), 432(1990), DOI:10.1248/cpb.38.432

46. S. Toda, Y. Shirataki, Pharmaceutical Biology, 42(1), 55(2004), DOI:10.1080/13880200490505537

47. E.Y. Chung, B.H. Kim, M.K. Lee, Y.P. Yun, S.H. Lee, K.R. Min, Y. Kim, Planta Medica, 69(8), 710(2003), DOI:10.1055/s-2003-42787.

48. E.Y. Chung, E. Roh, J.A. Kwak, H.S. Lee, S.H. Lee, C.K. Lee, S.B. Han, Y. Kim, Journal of Pharmacological Science, 112(4), 405(2010), DOI:10.1254/jphs.09247FP

49. S. Atun, Indonesian Journal of Chemistry, 9(1), 151(2009), DOI:10.22146/ijc.21578

50. P. Coggon, T.J. King, S.C. Wallwork, Chemical Communication, 13, 439(1966), DOI: $10.1039 / \mathrm{C} 19660000439$

51. E.H. Hakim, L.D. Juliawaty, Y.M. Syah, S.A. Achmad, J. Latip, E.L. Ghisalberti, Fitoterapia, 77(78), 550(2006), DOI:10.1016/j.fitote.2006.07.004

52. P. Sasikumar, B. Prabha, T. R. Reshmitha, Sheeba Veluthoor, A. K. Pradeep, K. R. Rohit, B. P. Dhanya, V. V. Sivan, M.M. Jithin, N. Anil-Kumar, I.G. Shibi, P. Nisha, K.V. Radhakrishnan, RSC Advances, 6(80), 77075(2016), DOI:10.1039/c6ra14334b.

53. S.Y. Lin, G.C. Huang, Y.Y. Hsieh, Y.S. Lin, C.H. Han, C.L. Wen, C.I. Chang, W.C. Hou, Journal of Agricultural and Food Chemistry, 63(42), 9286(2015), DOI:10.1021/acs.jafc.5b04269

54. H. Saroyobudiono, L.D. Juliawaty, Y.M. Syah, S.A. Achmad, E.H. Hakim, J. Latip, I.M. Said, Journal of Natural Medicines, 62(2), 195(2008), DOI:10.1007/s11418-007-0205-0.

55. T. Ito, Yakugaku Zasshi, 131(1), 93(2011), DOI:10.1248/yakushi.131.93

56. K.S. Jones, A.P. Alimov, H.L. Rilo, R.J. Jandacek, L.A. Woollett, W.T. Penberthy, Nutrition and Metabolism, 5(23), (2008), DOI:10.1186/1743-7075-5-23.

57. Y. Tabata, K. Takano, T. Ito, M. Inuma, T. Yoshimoto, H. Miura, Y. Kitao, S. Ogawa, O. Hori, American Journal of Physiology-Cell Physiology, 293(1). C411(2007), DOI: 10.1152/ajpcell.00095.2007

58. B. Basha, S. M. Samuel, C. R. Triggle, H. Ding, Experimental Diabetes Research, 2012, 481840(2012), DOI:10.1155/2012/481840

59. Y.S. Lin, C.R. Chen, W.H. Wu, C.L. Wen, C.I. Chang, W.C. Hou, Journal of Agricultural and Food Chemistry, 63(28), 6393(2015), DOI:10.1021/acs.jafc.5b02069

60. P.S. Su, R.J. Doerksen, S.H. Chen, W.C. Sung, C.C. Juan, R.D. Rawendra, C.R. Chen, J.W. Li, Aisha, T.C. Huang, M.H. Liao, C.I. Chang, J.L. Hsu, Journal of Pharmaceutical and Biomedical Analysis, 108, 70(2015), DOI:10.1016/j.jpba.2015.01.053

61. T. Tsukamoto, R. Nakata, E. Tamura, Y. Kosuge, A. Kariya, M. Katsukawa, S. Mishima, T. Ito, M. Iinuma, Y. Akao, Y. Nozawa, Y. Arai, S. Namura, H. Inoue, Nutrition and Metabolism, 7(46), 1(2010), DOI: 10.1186/1743-7075-7-46

62. N. Abe, T. Ito, K. Ohguchi, M. Nasu, Y. Masuda, M. Oyama, Y. Nozawa, M. Ito, M. Inuma, Journal of Natural Products, 73(9), 1499(2010), DOI:10.1021/np1002675

63. T. Ito, Y. Akao, K. Ohguchi, K. Matsumoto, T. Tanaka, M. Iinuma, Y. Nozawa, Carcinogenesis, 24(9), 1489(2003), DOI:10.1093/carcin/bgg105

64. T.L. Rachid, F.M. Silva-Veiga, F. Graus-Nunes, I. Bringhenti, C.A. Mandarim-de-Lacerda, V. SouzaMello, PLoS One, 13(1), (2018), DOI:10.1371/journal.pone.0191365

[RJC-5815/2020] 